\title{
SISTEM INFORMASI PENILAIAN HASIL BELAJAR SISWA SEKOLAH MENENGAH KEJURUAN (SMK) BERBASIS WEB
}

\author{
Achmad Sumbaryadi ${ }^{1}$, Petrus Christo ${ }^{2}$ \\ 1,2 Universitas Bina Sarana Informatika \\ Jln. Kamal Raya No. 18, Ringroad Barat, Cengkareng, Jakarta Barat \\ 1achmad.acs@bsi.ac.id \\ ${ }^{2}$ petrus.pcr@bsi.ac.id
}

\begin{abstract}
Abstrak - Penilaian dalam proses pembelajaran merupakan hal yang penting, sehingga dalam pengaplikasiannya pengolahan data nilai menjadi salah satu pilar yang penting. Pengolahan data nilai yang baik akan menghasilkan nilai raport sebagai hasil evaluasi yang baik pula, selain itu hasil pengolahan data nilai akan dijadikan sebagai salah satu tolak ukur keberhasilan siswa menempuh pendidikan di sekolah (Nursahid et al., 2015a:54). Untuk mendapatkan hasil dari pengolahan data nilai yang baik salah satunya dengan cara memanfaatkan teknologi yang ada dan sedang berkembang saat ini atau dengan kata lain membuat sistem pengolahan data nilai siswa dengan terkomputerisasi dalam hal ini berbasis website, selain hasil yang didapat dari proses pengolahan data lebih akurat, dengan menggunakan sistem terkomputerisasai berbasis website juga bisa lebih mempermudah kinerja dari dewan guru yang mengelola data nilai siswa di sekolah.. Tujuan utama penulisan "Sistem Informasi Penilaian Hasil Belajar Siswa Sekolah Menengah Kejuruan Berbasis Web Pada SMK Sirajul Falah Parung-Bogor". Dengan adanya sistem informasi ini diharapkan dapat mempermudah baik guru mata pelajaran, wali kelas dan pihak terkait dalam penyusunan dokumen-dokumen penilaian siswa dengan efektif dan efisien.
\end{abstract}

Kata kunci-Sistem Informasi, Perancangan Sistem Informasi, Web, Sekolah, SMK Sirajul Falah

\section{Pendahuluan}

Penilaian dalam proses pembelajaran merupakan hal yang penting, sehingga dalam pengaplikasiannya pengolahan data nilai menjadi salah satu pilar yang penting. Pengolahan data nilai yang baik akan menghasilkan nilai raport sebagai hasil evaluasi yang baik pula, selain itu hasil pengolahan data nilai akan dijadikan sebagai salah satu tolak ukur keberhasilan siswa menempuh pendidikan di sekolah (Nursahid et al., 2015a:54).

Untuk mendapatkan hasil dari pengolahan data nilai yang baik salah satunya dengan cara memanfaatkan teknologi yang ada dan sedang berkembang saat ini atau dengan kata lain membuat sistem pengolahan data nilai siswa dengan terkomputerisasi dalam hal ini berbasis website, selain hasil yang didapat dari proses pengolahan data lebih akurat, dengan menggunakan sistem terkomputerisasai berbasis website juga bisa lebih mempermudah kinerja dari dewan guru yang mengelola data nilai siswa di sekolah..

Tujuan utama penulisan "Sistem Informasi Penilaian Hasil Belajar Siswa Sekolah Menengah Kejuruan Berbasis Web
Pada SMK Sirajul Falah Parung-Bogor". Dengan adanya sistem informasi ini diharapkan dapat mempermudah baik guru mata pelajaran, wali kelas dan pihak terkait dalam penyusunan dokumen-dokumen penilaian siswa dengan efektif dan efisien, yang menyimpulkan bahwa "komputerisasi dapat mempermudah proses dalam kegiatan penilaian hasil belajar siswa yang dikerjakan oleh bapak atau ibu guru pengajar, terutama dalam penghitungan nilai, waktu rekap nilai, serta pembuatan laporan" (Nursahid et al., 2015b:62-63). Kemudian alasan sistem informasi berbasis web digunakan dalam pengolahan data nilai juga dikemukakan oleh Suryandani dkk (2017:72) "alasan sistem informasi berbasis web digunakan adalah kemudahan dalam cara mengaksesnya yaitu dengan cara mengakses lewat browser yang ada pada perangkat perangkat komputer atau perangkat telepon”.

\section{Metodologi Penelitian}

A. Metode Pengembangan Perangkat Lunak

Menurut Sukamto dan Shalahudin (2015:31) menjelaskan tentang metode pengembangan perangkat lunak yaitu prototipe. Model prototipe dapat digunakan untuk menyambungkan ketidak pahaman pelanggan mengenai hal teknis dan memperjelas spesifikasi kebutuhan yang diinginkan pelanggan kepada pengembang perangkat lunak. 
Tahapan pada model prototipe (prototyping model) dimulai dari:

1. Mendengarkan pelanggan (analisa kebutuhan perangkat lunak)

Pada tahap ini penulis menganalisa sistem pengolahan data nilai yang berjalan di SMK Sirajul Falah Parung-Bogor. Yakni: login hanya bisa dilakukan oleh (Staff TU, Wali Kelas serta Guru Mata Pelajaran). Staff TU bisa menambahkan mengedit serta menghapus (data guru, data kelas, data wali kelas, data siswa serta data mata pelajaran) dan bisa melihat laporan nilai serta mencetaknya. Wali Kelas bisa melihat data siswa, melihat daftar niali siswa serta membuat leger kelas. Guru Mata Pelajaran bisa menambah, mengedit dan menghapus nilai siswa (harian, UTS dan UAS) dan membuat daftar nilai siswa.

2. Membangun atau memperbaiki Mock-up

Menurut Sukamto dan Shalahuddin (2015:32) "Mock-up adalah sesuatu yang digunakan sebagai model desain yang digunakan untuk mengajar, demonstarasi, evaluasi desain, promosi, atau keperluan lainnya."

Pada tahap ini penulis menggunakan aplikasi Adobe Dreamweaver Cs5, Xampp, Jquery, dan Adobe Photoshop Cs5 untuk membangun atau memperbaiki mock-up dari sistem pengolahan data nilai tersebut.

3. Pelanggan melihat atau menguji Mock-up

Pada tahapan ini penulis menguji mock-up sistem pengolahan data nilai yang sudah dibuat dengan menggunakan User Acceptance Test (UAT). Juga memperlihatkan hasilnya pada pihak sekolah SMK Sirajul Falah Parung-Bogor, apakah sudah sesuai kebutuhan atau belum.

B. Teknik Pengumpulan Data

Adapun informasi yang disajikna dalam makalah ini, merupakan hasil dari proses pencarian data yang dilakukan baik selama riset lapangan maupun diluar dari kegitan itu. Secara detail kami telah melakukan beberapa metode penelitian, diantaranya :

1. Metode Observasi (Pengamatan )

Penulis melakukan observasi secara langsung pada SMK Sirajul Falah Parung agar dapat mengamati kegiatan yang memiliki keterkaitan dengan masalah yang diambil. Hasil dari pengamatan tersebut akan dicatat dan hasil pengamatan ini dapat kita ketahui proses dan kegitan tersebut beserta kekurangannya.

2. Metode Wawancara ( Interview )

Tujuan penulis menggunkan metode wawancara adalah untuk mencari dan memeriksa kebenaran suatu informasi dam juga mendapatkan informasi yang lebih jelas dan lebih spesifik lagi. Dalam metode ini penulis melakukan wawancara kepada Bpk. Herman Hardiansyah, S.SI selaku ketua Jurusan Teknik Komputer Jaringan di SMK Sirajul Falah Parung-Bogor.

\section{Studi Pustaka ( Library Research )}

Sebagai sarana bantu dalam penulisan makalah ini, penulis melakukan studi kepustakaan dengan mengunakan referensi - referensi yang relevan dengan permasalahan yang diangkat.

\section{HASIL DAN PEMBAHASAN}

3.1 Tahapan Perancangan Sistem

3.1.1 Analisis Kebutuhan

A. Kebutuhan Pengguna

Dalam sistem informasi pengolahan data nilai siswa ini terdapat 3 pengguna yang dapat saling berinteraksi dalam lingkungan sistem, yaitu: Staff TU, Wali Kelas dan Guru Mata Pelajaran. Ketiga pengguna tersebut memiliki karakteristik interaksi dengan sistem yang berbeda-beda dan memiliki kebutuhan informasi yang berbeda pula, seperti berikut:

1. Skenario Kebutuhan Staff TU

a. Memilih hak akses

b. Melakukan login

c. Mengelola data pribadi

d. Mengelola data kelas

e. Mengelola data siswa

f. Mengelola data wali kelas

g. Mengelola data mata pelajaran

h. Mengelola data guru

i. Melihat dan mencetak laporan nilai

2. Skenario Kebutuhan Wali Kelas
a. Memilih hak akses
b. Melakukan login
c. Mengelola data pribadi
d. Melihat data siswa
e. Melihat daftar nilai siswa
f. Mengelola leger kelas
3. Skenario Kebutuhan Guru Mata Pelajaran
a. Memilih hak akses
b. Melakukan login
c. Mengelola data pribadi
d. Mengelola nilai harian
e. Mengelola nilai uts
f. Mengelola nilai uas
g. Mengelola daftar nilai siswa

B. Kebutuhan Sistem

1. Pengguna harus memilih hak akses sesuai dengan perannya terlebih dahulu sebelum melakukan login

2. Pengguna harus melakukan login untuk dapat masuk kedalam program berbasis web ini dengan memasukkan username dan password

3. Pengguna harus melakukan logout setelah selesai menggunakan program

4. Sistem melakukan kalkulasi jumlah nilai, rata-rata nilai, predikat serta rangking. 


\subsubsection{Rancangan Sistem}

A. Use Case Pengolahan Data

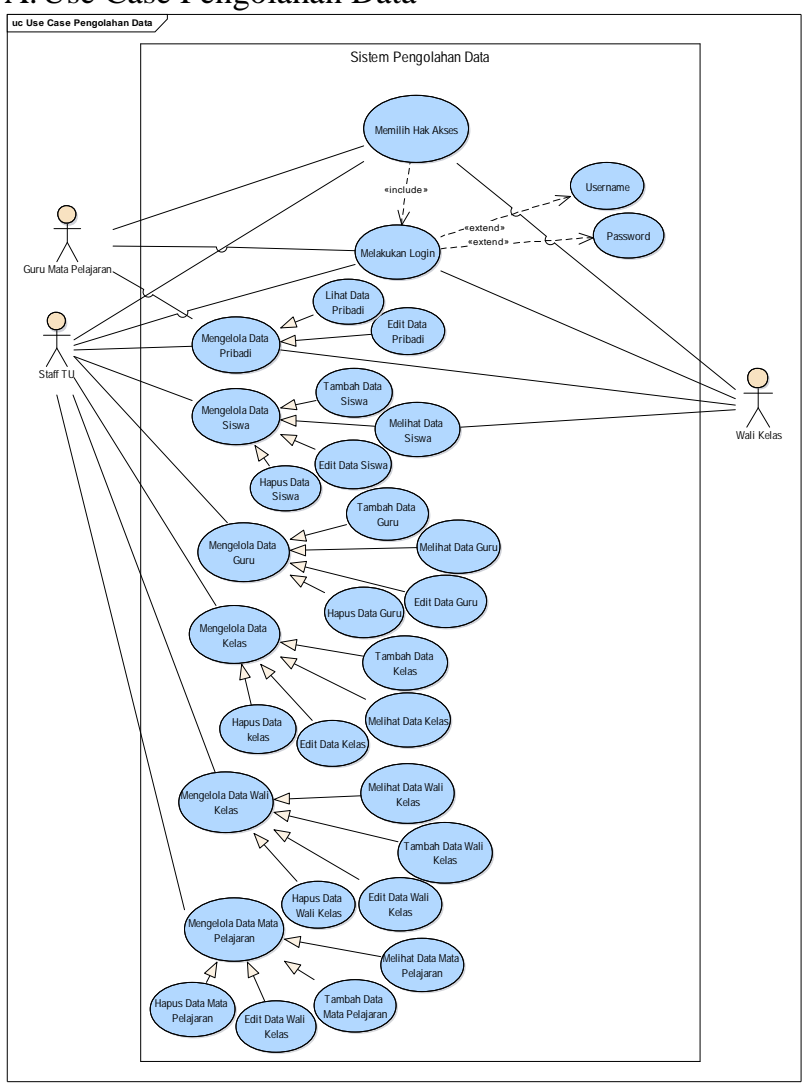

Gambar 1. Use Case Pengolahan Data

TABEL I

Deskripsi Use Case Memilih Hak Akses

\begin{tabular}{l|l}
\hline Use Case Name & Memilih Hak Akses \\
\hline Requirements & $\begin{array}{l}\text { Staff TU, Wali Kelas dan } \\
\text { Guru Mata Pelajaran } \\
\text { dapat memilih hak akses }\end{array}$ \\
\hline Goal & $\begin{array}{l}\text { Staff TU, Wali Kelas dan } \\
\text { Guru Mata Pelajaran } \\
\text { dapat memilih hak akses } \\
\text { sesuai dengan hak } \\
\text { aksesnya masing-masing } \\
\text { pada web }\end{array}$ \\
\hline Pre-Conditions & $\begin{array}{l}\text { Staff TU, Wali Kelas dan } \\
\text { Guru Mata Pelajaran } \\
\text { mengakses alamat web } \\
\text { pengolahan data nilai } \\
\text { siswa SMK Sirajul Falah } \\
\text { Parung-Bogor }\end{array}$ \\
\hline
\end{tabular}

\begin{tabular}{|c|c|}
\hline Post-Conditions & $\begin{array}{l}\text { Sistem menampilkan } \\
\text { menu login }\end{array}$ \\
\hline Failed end Condition & $\begin{array}{l}\text { Staff TU, Wali Kelas dan } \\
\text { Guru Mata Pelajaran } \\
\text { tidak dapat memilih hak } \\
\text { akses }\end{array}$ \\
\hline Actors & $\begin{array}{ll}\text { 1. } & \text { Staff TU } \\
\text { 2. } & \text { Wali Kelas } \\
\text { 3. } & \text { Guru Mata } \\
& \text { Pelajaran }\end{array}$ \\
\hline $\begin{array}{l}\text { Main Flow / Basic } \\
\text { Path }\end{array}$ & $\begin{array}{ll}\text { 1. } & \text { Staff TU, Wali } \\
\text { Kelas dan Guru } \\
\text { Mata Pelajaran } \\
\text { mengakses alamat } \\
\text { web pengolahan } \\
\text { data nilai siswa } \\
\text { SMK Sirajul Falah } \\
\text { Parung-Bogor } \\
\text { 2. } \\
\text { Staff TU, Wali } \\
\text { Kelas dan Guru } \\
\text { Mata Pelajaran } \\
\text { memilih hak akses } \\
\text { sesuai dengan hak } \\
\text { aksesnya masing- } \\
\text { masing } \\
\text { Sistem } \\
\text { menampilkan menu } \\
\text { login sesuai hak } \\
\text { akses }\end{array}$ \\
\hline $\begin{array}{l}\text { Alternate } \\
\text { Flow/Invariant A }\end{array}$ & $\begin{array}{ll}\text { A1. } & \text { Sistem } \\
\text { menampilkan menu } \\
\text { login yang tidak } \\
\text { sesuai hak akses }\end{array}$ \\
\hline Invariant B & $\begin{array}{ll}\text { B1. } & \text { Staff TU, Wali } \\
\text { Kelas dan Guru } \\
\text { Mata Pelajaran } \\
\text { mengakses alamat } \\
\text { web pengolahan } \\
\text { data nilai siswa } \\
\text { SMK Sirajul Falah } \\
\text { Parung-Bogor } \\
\text { B2. } \\
\text { Sistem } \\
\text { menampilkan pesan } \\
\text { "website sedang } \\
\text { tidak bisa diakses" }\end{array}$ \\
\hline
\end{tabular}




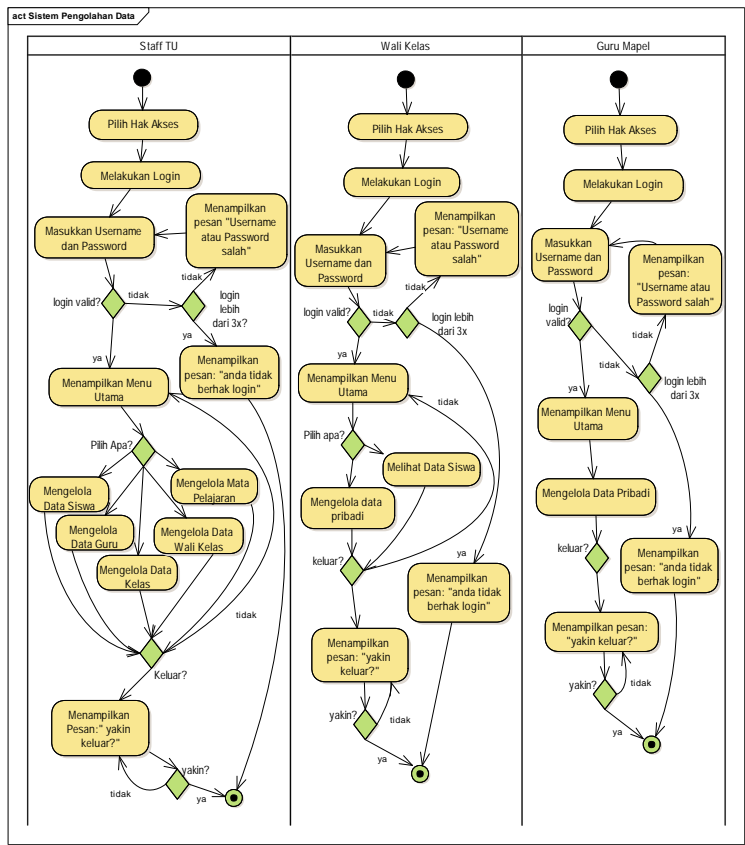

Gambar 2.Diagram Aktifitas Pengolahan Data

\subsubsection{Rancangan Prototype}

a. Interface Pilih Hak Akses Sistem Pengolahan Data Nilai Siswa SMK Sirajul Falah Parung-Bogor

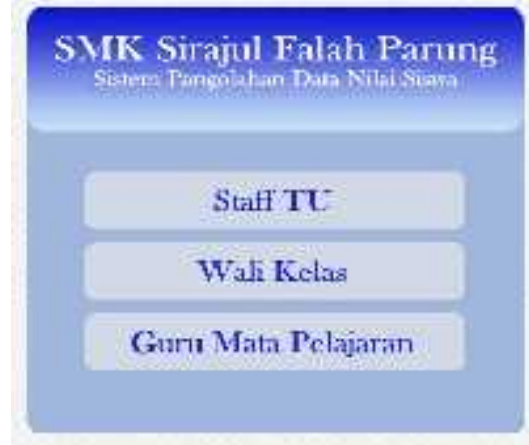

Gambar 3.Rancangan Tampilan Hak Akses

b.Interface Form Login Untuk Staff TU

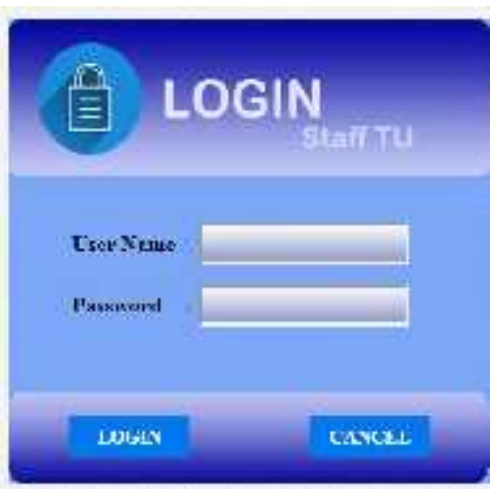

Gambar 4.Rancangan Tampilan Form Login Staff TU c.Interface Menu Home Staff TU

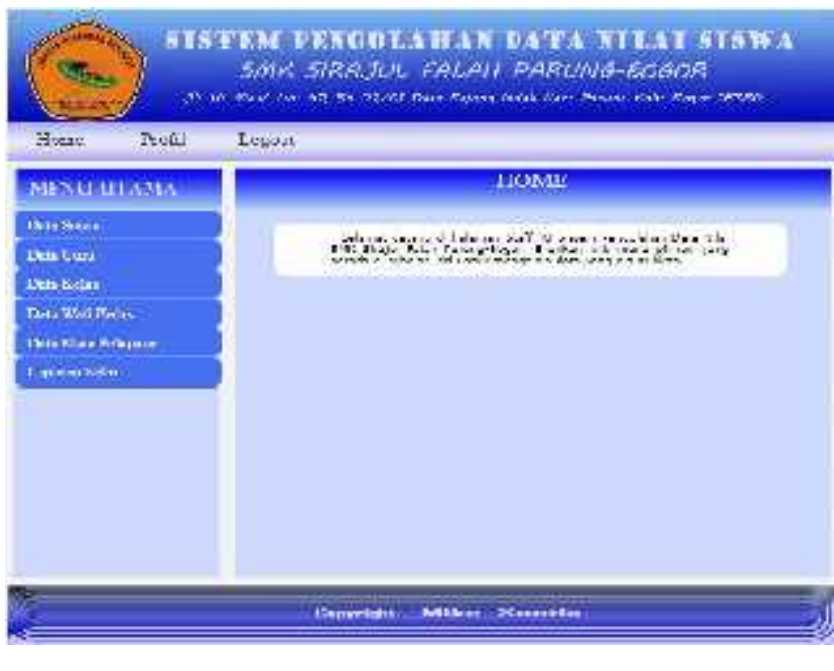

Gambar 5.Rancangan Tampilan Menu Home Staff TU

d.Interface Menu Home Data Siswa

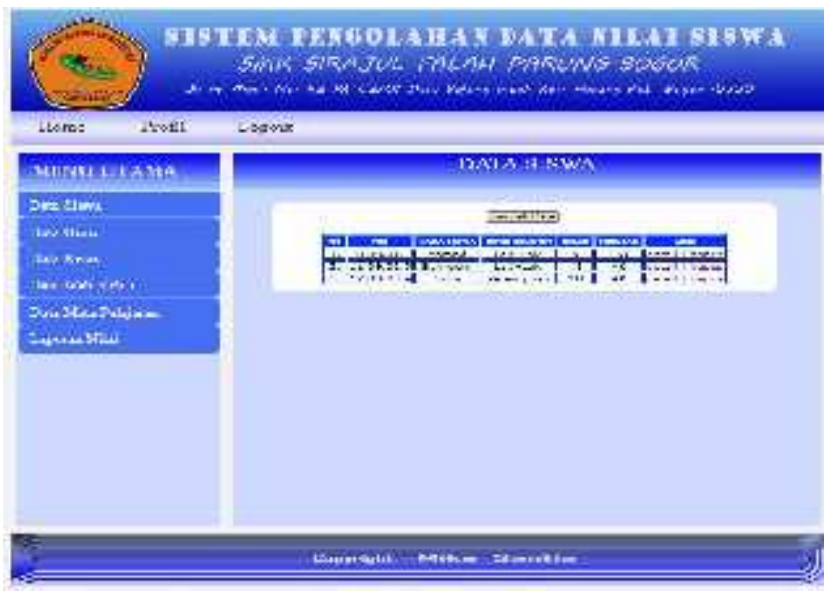

Gambar 6.Rancangan Tampilan Menu Data Siswa

e.Interface Menu Home Data Guru 


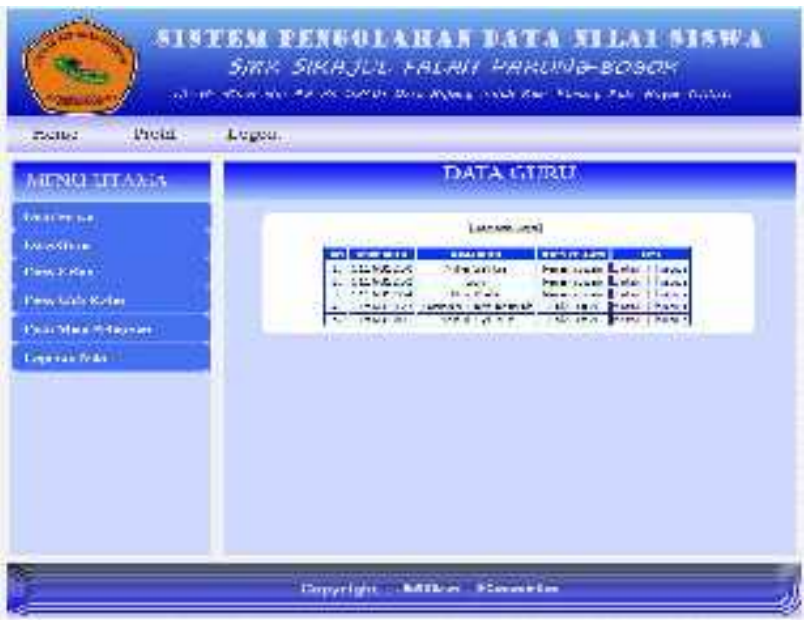

Gambar 7.Rancangan Tampilan Menu Data Guru

\section{f.Rancangan ERD}

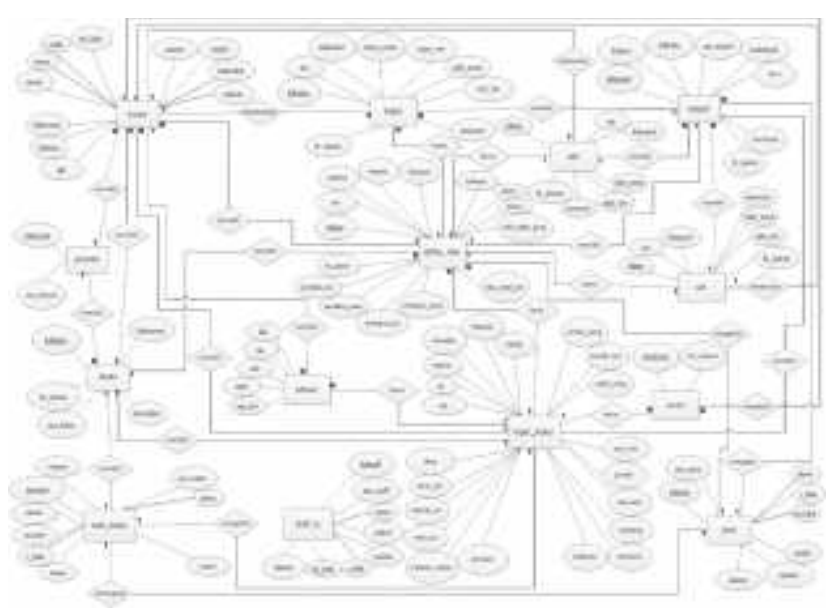

Gambar 8.Rancangan ERD

g.Rancangan LRS

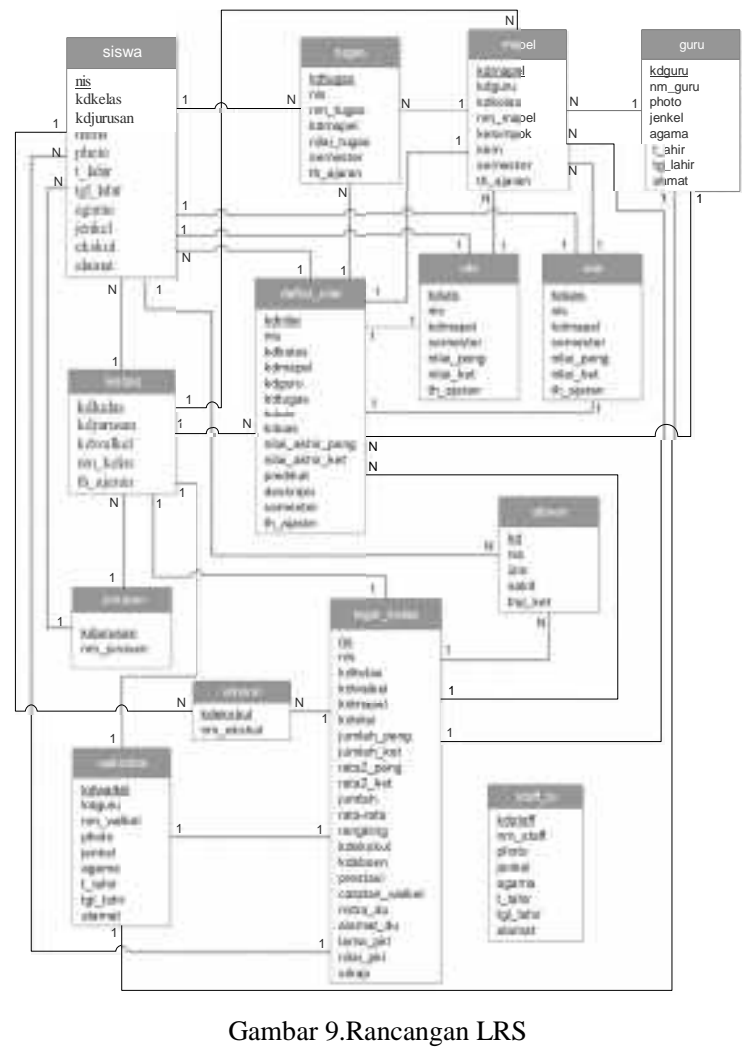

h.Rancangan Sequennce Diagram

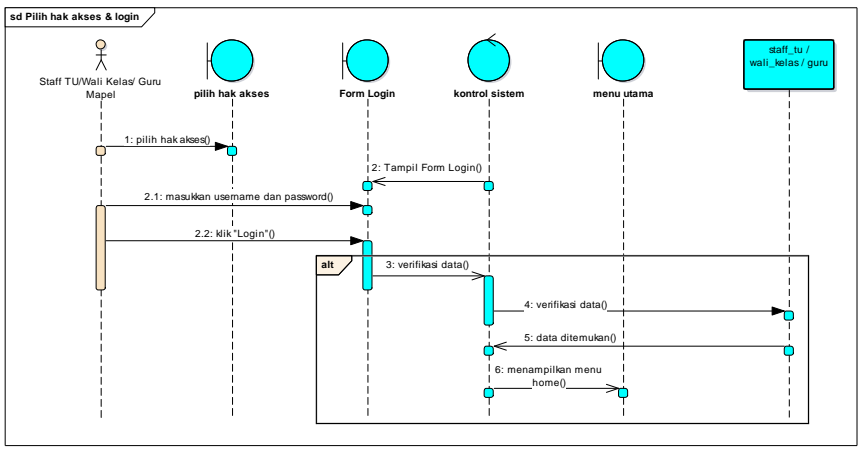

Gambar 10.Rancangan Sequence Diagram

IV. KESIMPULAN

Berdasarkan hasil dari penulisan ini dapat disimpulkan bahwa:

1. Penggunaan sistem informasi pengolahan data nilai berbasis web pada SMK Sirajul Falah Parung-Bogor dapat 
memberikan solusi yang lebih cepat dalam pengelolaan data nilai siswa,

2. Lebih cepat dalam pencarian data nilai siswa yang dibutuhkan,

3. Pembuatan laporan nilai siswa pun bisa lebih efektif dan efisien karena penyimpanan data sudah dalam database,

4. Untuk menggunakan sistem ini pengguna harus memilih hak akses dan melakukan login terlebih dahulu

\section{UCAPAN TERIMA KASIH}

Penulis menyampaikan terima kasih kepada orang-orang yang berhubungan denganpenelitian yang dibuat:

1) Kepada Allah Yang Maha Kuasa yang telah memberi kesempatan dalam kehidupan,kesehatan, rejeki dan pembelajaran.

2) Kepada segenap Pimpinan, Staff dan rekan dosen di lingkungan AMIK BSI dan STMIK Nusa Mandiri Jakarta.

3) Kepada segenap Pimpinan, Dosen dan Staff Universitas Serang di Serang

4) Kepada segenap Staff LPPM Unsera di Serang

5) Kepada orangtua, saudara, sahabat dan rekan lainnya yang tidak dapat disebutkan satupersatu yang telah memberikan bantuan, semangat dan perhatian baik langsung maupuntidak langsung.

\section{REFERENSI}

[1] Kaafi, A. Al, and Syahriani, "Sistem Informasi Penjualan Pakaian Berbasis Web", in Konferensi Nasional Ilmu Sosial \& Teknologi (KNiST), 2016, p277-282.

[2] Kostaman, N. and Sumaryana, Y,"Aplikasi Pemesanan Tiket Oto Bus Budiman Berbasis Online", Jurnal Manajemen Dan Teknik Informatika (Jumantak), Retrieved from http://jurnal.stmikdci.ac.id/index.php/jumantaka/article/view/275/0

[3] Lipursari, A,’Peran Sistem Informasi Manajemen (Sim) Dalam Pengambilan Keputusan", Jurnal Stie Semarang, 5(1), 26-37. https://doi.org/2252-7826

[4] Nursahid, Riasti, B. and Purnama, B,'Pembangunan sistem informasi penilaian hasil belajar siswa Sekolah Menengah Atas (SMA) Negeri 2 Rembang berbasis web" Ijns.Org, 4(2), 54-63. Retrieved from http://www.ijns.org/journal/index.php/ijns/article/view/ 1339

[5] Suryandani, F., Basori, B. and Maryono, D., "Pengembangan Sistem Informasi Akademik Berbasis Web Sebagai Sistem Pengolahan Nilai Siswa Di Smk Negeri 1 Kudus",. Jurnal Ilmiah Pendidikan Teknik
Dan Kejuruan, $\quad$ 10(1), 71-82. https://doi.org/10.20961/jiptek.v10i1.14976

[6] Sukamto, R. A., and Salahudin, M., Rekayasa Perangkat Lunak. Bandung: Informatika, 2015

[7] Susanti, M.,'Perancangan Sistem Informasi Akademik Berbasis Web Pada Smk Pasar Minggu Jakarta", Jurnal Informatika, 3(1). https://doi.org/10.31311/JI.V3I1.304

[8] Syafii, and Kusumawardani, H. H,"Sistem Informasi Pengolahan Nilai Siswa Berbasis Web Pada Smk Muhammadiyah Karanganyar",Jurnal Surya Informatika, 2(1).Retrieved from http://ejournal.politeknikmuhpkl.ac.id/index.php/surya _informatika/article/view/26

[9] Widagdo, S., \& Kurnia, E. D., "Nilai Pendidikan Dalam Upacara Tradisi Haul Semangkin Di Desa Mayong Lor Kecamatan Mayong Kabupaten Jepara” Journal.Unnes.Ac.Id, 37-47. Retrieved from http://journal.unnes.ac.id/nju/index.php/lingua/article/v iew/2978 